DOI: https://doi.org/10.47405/mjssh.v6i9.1052

\begin{tabular}{|c|c|}
\hline 4.581 & Malaysian Journal of Social Sciences and Humanities (MJSSH) \\
\hline $\begin{array}{l}\text { Malaysian Journal of } \\
\text { Social cciences and }\end{array}$ & Volume 6, Issue 9, September 2021 \\
\hline (MJ-SSH) & e-ISSN : 2504-8562 \\
\hline & $\begin{array}{l}\text { Journal home page: } \\
\text { www.msocialsciences.com }\end{array}$ \\
\hline
\end{tabular}

\title{
Naratif Sosiologi Pendatang Asing Tanpa Izin (PATI) Indonesia: Satu Kajian Fenomenologi
}

\author{
Azizah Adib Rahim ${ }^{1}$, Novel Lyndon' ${ }^{1}$ \\ ${ }^{1}$ Fakulti Sains Sosial dan Kemanusiaan, Universiti Kebangsaan Malaysia (UKM) \\ Correspondence: Azizah Adib Rahim (azizahadibrahim59@gmail.com)
}

\begin{abstract}
Abstrak
Migrasi antarabangsa telah dibincangkan dalam pelbagai disiplin seperti politik, ekonomi, geografi dan sosiologi. Perbincangan ini sangat penting untuk memahami mengapa migrasi berlaku sejak dulu dan faktor-faktornya bergantung kepada ekonomi, sosial dan politik. Oleh kerana kemasukan pendatang asing tanpa izin (PATI) di Malaysia semakin meningkat, penguatkuasaan yang strategik sangat penting untuk mengekang permasalahan yang telah berlaku sejak sekian lama ini. Oleh itu, kajian ini dilakukan untuk mengenal pasti faktor Malaysia dipilih sebagai destinasi utama dalam kalangan PATI Indonesia. Kajian ini dilakukan melalui pendekatan fenomenologi di mana penyelidik memberi fokus kepada perspektif informan. Sesi temubual mendalam telah dilakukan bersama dengan 10 informan yang dipilih mengikut teknik pensampelan bertujuan dan bola salji. Kajian ini mendapati faktor mengapa Malaysia dipilih sebagai destinasi uttama merangkumi dua aspek iaitu ekonomi dan sosio-budaya. Aspek ekonomi merangkumi keperluan, peluang pekerjaan dan upah yang lebih tinggi. Sementara itu, aspek sosial merangkumi bahasa, agama, budaya dan norma sosial. Sebagai kesimpulan, para informan menyentuh aspek ekonomi dan sosial sebagai faktor utama mereka untuk berhijrah ke Malaysia. Ini menunjukkan bahawa PATI membuat keputusan untuk mereka berhijrah berdasarkan faktor ekonomi dan sosio-budaya. Faktor ekonomi menjadi tarikan untuk PATI bermigrasi ke Malaysia, tetapi yang faktor sosio-budaya yang membuatkan mereka kekal tinggal di Malaysia.
\end{abstract}

Kata kunci: migrasi antarabangsa, pendatang asing tanpa izin, penguatkuasaan yang strategik

\section{The Sociological Narrative of Indonesian, Illegal Immigrants about Malaysia: A phenomenological study}

\begin{abstract}
International migration has been discussed in various of multidisciplinary approaches such as political, economics, geography and sociology. These discussions are crucial to understand why migration occurs since before and the factors depend on the economy, social and politically landscape. Due to the influx of illegal immigrants in Malaysia, strategic enforcement is crucial to curb the on - going issue. Hence, the study is conducted to identify the factors of why Malaysia is chosen as the first destination among Indonesians illegal immigrants. The study is conducted through phenomenology approach where the researcher prioritizes the informants' perspectives. Series of in-depth interviews are conducted among 10 informants who were chosen according to purposive and snowball sampling technique. The study found the factors of why Malaysia is chosen as the first destination covers two aspects which are economy and socio-culture. Economy aspect comprises needs, job opportunities and high wages. Meanwhile, social aspect covers languages, religion, culture and social norm. To conclude,
\end{abstract}


the informants mostly touched on economy and social aspects as their main driven factors to migrate to Malaysia. It shows that the illegal immigrants consider their decision in accordance to economy and social dualism. The latter entice them to travel to Malaysia, but the former what makes them stay in Malaysia.

Keywords: international migration, illegal immigrants, strategic enforcement

\section{Pengenalan}

Migrasi antarabangsa telah dibincangkan dalam pelbagai disiplin seperti politik, ekonomi, geografi dan sosiologi. Perbincangan ini sangat penting untuk memahami mengapa migrasi berlaku sejak dari dulu. Faktor-faktor tersebut bergantung pada ekonomi, sosial dan landskap politik. Teori Migrasi yang terkenal dipelopori oleh Lee (1966) yang juga dikenali sebagai Faktor Penarik dan Penolak. Menurut Anggoro (2019), Lee menentukan tiga elemen penting dalam menentukan keputusan migrasi dalam kalangan imigran. Elemen tersebut adalah tempat asal, destinasi yang dituju, faktor peribadi dan halangan yang mengganggu. Sementara itu, Haug (2008) pula menyatakan jaringan sosial yang terjalin antara imigran dan agen sosialisasi utamanya juga berfungsi sebagai faktor pendorong atau tarikan. Sebagai contoh, keluarga yang mendorong ahli keluarga mereka untuk bekerja di luar negara bagi meneruskan kelangsungan kehidupan. Di samping itu, Dorigo dan Tobler (1983), menyebut keadaan kehidupan menyebabkan seseorang tidak berpuas hati dengan tempat asal mereka dan bertindak sebagai faktor pendorong dan tarikan-tarikan dari tempat yang lain diklasifikasikan sebagai faktor penarik.

Walaupun begitu, para sarjana lain berpendapat bahawa faktor makro tidak dapat memberikan penjelasan mengapa migrasi besar-besaran tidak selalunya berlaku di sesetengah tempat yang lain. Beberapa tempat dengan faktor tolakan dan tarikan yang serupa menghasilkan migrasi besar-besaran sementara di tempat lain, migrasi hampir tidak wujud (Boswell, 2002). Oleh itu, meso dan mikro dapat mengisi persoalan tersebut. Tidak seperti teori tolakan dan tarikan yang memfokuskan kepada tempat asal dan destinasi yang dituju, meso dan mikro menekankan pada sistem dan jaringan sosial di kalangan imigran dan ejen sosialisasi. Tahap mikro saling berkaitan dengan aspek peribadi yang mendalam berkisar kepada hubungan kekeluargaan, saudara dan jiran dan proses dalaman individu. Sebagai contoh, faktor pendorong dari keluarga untuk bekerja di luar negara untuk meningkatkan kehidupan seperti yang disebutkan oleh Haug (2008). Sebaliknya, tahap meso menekankan pada jaringan sosial imigran bersama agen sosial dalam persekitaran sosial mereka yang mendorong mereka untuk melakukan perjalanan dengan status haram (Boswell, 2002; Ridwan, 2017). Malahan, Boswell (2002) turut menyatakan bahawa tahap mikro bertindak sebagai pemeriksaan dan kawalan terhadap tahap meso dan makro. Dengan kata lain, dorongan dari jaringan sosial imigran dan faktor tolakan dan tarikan diteliti lebih lanjut oleh proses dalaman individu.

Sementara itu, pendekatan lain adalah ekonomi neoklasik yang merupakan lanjutan kepada teori klasik. Ekonomi neoklasik menekankan kos faedah melalui perbezaan upah antara negara asal dan negara destinasi (Douglas \& Espinosa, 1997; Hazan, 2014). Sebagai contoh, imigran Mexico akan menganalisis pendapatan mereka di Mexico dan berapa banyak yang dapat mereka perolehi di A.S. Upah yang diharapkan dapat menentukan keputusan imigran sama ada mereka harus berhijrah atau tidak. Namun, teori ini mendapat kritikan daripada ekonomi baru migrasi buruh. Pandangan itu memfokuskan pada sudut pandang rumah tangga dan bukannya sudut pandang individu serta kegagalan pasaran di negara asal (Douglas \& Espinosa, 1997; Hazan, 2014). Matlamat khusus imigran adalah untuk mengumpul wang dari negara penerima dan kembali ke tanah air untuk membantu keluarga mereka. Kerana kegagalan pasaran di tanah air mereka, mereka mempelbagaikan sumber daya yang ada untuk mengakses modal dengan berhijrah ke negara penerima dengan tujuan untuk mengumpulkan wang. Sama ada faktor tolakan dan tarikan, tahap meso dan mikro dan pandangan ekonomi neoklasik dan baru, para sarjana telah menunjukkan definisi yang konsisten bahawa faktor-faktor migrasi antarabangsa merangkumi faktor dalaman dan luaran yang mempengaruhi keputusan imigran mahupun PATI. 
PATI sering dikenali dengan pelbagai istilah seperti PATI asing atau PATI tanpa dokumen. Istilahistilah ini juga dihubungkan dengan jargon lain seperti pencari suaka dan 'pelarian. Semua istilah ini membawa makna yang hampir sama tetapi mempunyai perbezaan yang kecil yang menjadikan definisi setiap terminologi berbeza. PATI merujuk kepada orang-orang yang berhijrah ke negara yang berbeza secara sukarela kerana pelbagai faktor yang telah dibincangkan sebelumnya. Penghijrahan dilakukan tanpa pengetahuan pemerintah negara penerima kerana migrasi tersebut dilakukan tanpa dokumen yang mengikut lunas undang - undang negara (McBrien, 2017). Sebaliknya, pencari suaka didefinisikan sebagai orang yang melarikan diri dari tanah air kerana takut akan kehidupan mereka sendiri dan orang yang mencari perlindungan antarabangsa (McBrien, 2017; Phillips, 2011). Namun, secara rasmi mereka masih belum dikenal pasti sebagai pelarian kerana mereka melalui proses dokumentasi yang betul di bawah UNHCR. Pencari suaka dan pelarian mempunyai alasan yang sama untuk berhijrah ke negara yang berbeza. Walau bagaimanapun, pelarian telah diakui oleh UNHCR sebagai pelarian dan mereka berada di bawah perlindungan oleh organisasi (McBrien, 2017). Oleh itu, orang yang melarikan diri dari tanah air akan datang ke destinasi yang dituju sebagai pencari suaka dan mereka akan dikenali sebagai pelarian setelah mereka mempunyai dokumentasi rasmi dari UNHCR.

Walaupun begitu, Malaysia tidak pernah mengesahkan Konvensyen Pertubuhan Bangsa-Bangsa Bersatu 1951 berkaitan dengan Status Pelarian dan Protokol 1967. Negara lain yang mengambil langkah yang sama adalah Pakistan dan Indonesia. Keprihatinan terbesar kerajaan Malaysia adalah penerimaan Malaysia terhadap 100,000 orang di kem kerana lokasi geografi yang strategik akan menarik perhatian lebih banyak pelarian untuk berhijrah ke Malaysia (Leigh, 2012). Oleh kerana Malaysia adalah negara yang tidak menandatangani perjanjian tersebut, pelarian di Malaysia masih dianggap sebagai PATI. Ini kerana hanya ada dua jenis imigran di Malaysia iaitu PATI dan imigran yang mempunyai dokumen yang sah (Zuraidah \& Lee, 2014). Peningkatan bilangan PATI mengakibatkan masalah lain dari segi sosial, politik dan ekonomi. Contohnya, peluang jenayah dan pekerjaan di kalangan penduduk tempatan. Oleh itu, penguatkuasaan strategik sangat penting untuk mengekang masalah yang sedang berlaku. Kajian ini dilakukan untuk mengenal pasti faktor mengapa Malaysia dipilih sebagai destinasi utama di kalangan PATI Indonesia.

\section{Migrasi Dari Indonesia Ke Malaysia}

Peradaban Melayu dibina dengan gabungan kerajaan-kerajaan Melayu lama dari Tanah Melayu dan Indonesia. Oleh kerana tidak ada sempadan nasional pada waktu sebelumnya, Dunia Melayu dilihat sebagai satu merangkumi Kerajaan Majapahit, Perlak, Pasai, Melaka, Jambi dan beberapa kerajaan Melayu lama yang lain (Taufiq, Tuan Nurhafiza, Ahmad Faqih, \& Muhammad Hilmi, 2019). Walaupun begitu, semasa penjajahan Inggeris dan Belanda, Dunia Melayu dibahagikan mengikut kekuatan dan pemerintahan politik. Perjanjian Anglo - Belanda pada tahun 1824 telah direkodkan dalam sejarah bahawa Dunia Melayu telah dibahagikan dengan dua kekuatan politik yang berbeza. Menurut perjanjian itu, Tanah Melayu diperintah oleh Inggeris dan kemudian dipanggil sebagai Persekutuan Tanah Melayu, sementara itu Indonesia pula diperintah oleh Belanda. Agenda tersembunyi British dalam melaksanakan dasar 'pecah dan perintah' adalah untuk mencegah penyatuan dalam kalangan penduduk tempatan (Taufiq, Tuan Nurhafiza, Ahmad Faqih, \& Muhammad Hilmi, 2019).

Usaha berterusan dari para pemimpin untuk menyatukan penduduk tempatan yang berasal dari pelbagai latar belakang kaum dicatat dalam sejarah. Akhirnya, warganegara secara keseluruhan berjaya memerangi Malayan Union, idea yang dinyatakan oleh British dengan formasi baru mereka yang disebut United Malays Organisation (UMNO). Penduduk tempatan menentang Malayan Union kerana kaedah Harold Mac Michael yang mendapat persetujuan dari sultan dalam jangka masa yang singkat. Persekutuan Tanah Melayu akhirnya merdeka pada 31 Ogos 1957 dan pada tahun 1963, Malaysia digabung dengan Sabah, Sarawak dan Singapura. Sejak kemerdekaan, pemerintah Malaysia telah melaksanakan pelbagai dasar strategik untuk mengembangkan ekonomi. Ini turut dinyatakan oleh (Taufiq, Tuan Nurhafiza, Ahmad Faqih, \& Muhammad Hilmi, 2019) kegiatan ekonomi yang rancak berlaku dengan memberi fokus utama kepada sektor perindustrian dan perkhidmatan berbanding sektor pertanian. 
Berikutan daripada aktiviti ekonomi yang pesat tersebut, Malaysia menghadapi kekurangan tenaga kerja pada tahun 1970 hingga 1980. Pembangunan negara memerlukan tenaga kerja berkemahiran tinggi sehinggalah pekerja berkemahiran rendah terutamanya di sektor pembinaan. Oleh itu, untuk mengisi kekosongan tersebut, pemerintah Malaysia melaksanakan dasar pengambilan pekerja asing dari pelbagai negara termasuk Indonesia. Menurut Tunira (2015) migrasi Indonesia meningkat dengan pesat di bawah era Suharto pada tahun 1980-an. Jumlah pekerja Indonesia meningkat semasa krisis ekonomi pada tahun 1990. Ekonomi Indonesia terjejas berikutan tidak ada pekerjaan yang cukup untuk rakyat dan kepadatan penduduk yang tinggi di Indonesia. Oleh itu, sebahagian besar daripada mereka berhijrah ke Malaysia untuk memperbaiki keadaan hidup mereka dengan mencari peluang pekerjaan. Faktor lain mengapa kerajaan memilih pekerja asing adalah kerana penduduk tempatan tidak mahu memilih pekerjaan dengan gaji rendah. Kekosongan di pasaran buruh menjadi daya tarikan untuk menarik orang Indonesia yang berhijrah ke Malaysia (Taufiq, Tuan Nurhafiza, Ahmad Faqih, \& Muhammad Hilmi, 2019).

Pada tahun 1981, agensi kerajaan Malaysia memperuntukkan blok tanah kepada pekebun kecil kerana pelaksanaan dasar FELDA. Objektif utama projek ini adalah untuk membantu pekebun kecil mengembangkan sektor pertanian. Dalam tempoh itu, sebilangan besar pekerja asing diperlukan untuk membantu menebang pokok dan kerja rencam yang lain (Kaur, 2015). Kerajaan kemudian beralih kepada orang Indonesia dan Thailand untuk mendapatkan bekalan tenaga kerja. Malahan, kerajaan turut mengupah PATI, mengabaikan status mereka dan kemungkinan masalah yang akan timbul. Pekerja Indonesia merupakan pilihan utama kerana stok perkauman yang sama dengan rakyat Malaysia (Kaur, 2015). Walaupun begitu, berikutan pelaksanaan polisi imigresen yang lemah, sebahagian besar dari mereka migrasi ke Malaysia haram dan jumlah mereka semakin meningkat.

Justeru, untuk memerangi masalah tersebut, kerajaan melaksanakan Sistem Permit Kerja pada tahun 1982. Jawatankuasa Pengambilan Pekerja Asing ditubuhkan untuk membantu kerajaan memperuntukkan izin kerja kepada pekerja asing (Kaur, 2015). Pada tahun 1984, Perjanjian Medan ditandatangani oleh pemerintah Malaysia dan Indonesia untuk menyeragamkan prosedur pengambilan pekerja (Suradji, 2006; Kaur, 2015). Pekerjaan yang ditawarkan kepada orang Indonesia kebanyakannya adalah di sektor pertanian dan perkebunan domestik. Kongres Kesatuan Sekerja Malaysia (MTUC) kemudian menyatakan keprihatinan mereka terhadap peningkatan jumlah PATI. Task Force VII kemudiannya mengambil alih untuk mencegah pendaratan kapal Indonesia (Kaur, 2015). Namun, dasar itu berubah kerana keuntungan politik. Pada tahun 1991, penguatkuasaan diperkuat kembali dengan pelaksanaan Ops Nyah I dan Ops Nyah II untuk mengurangkan migrasi haram dan sementara itu untuk mengesahkan status PATI melalui program pendaftaran dan pengampunan (Kaur, 2015).

Hubungan dua hala antara Malaysia dan Indonesia bertaut sejak sekian lama seperti yang direkodkan oleh sejarah. Indonesia dan Malaysia mempunyai persamaan yang identikal terutama dari sudut identiti sosial negara seperti budaya, warisan, agama dan bangsa (Maiwan, 2012; Tunira, 2015; Taufiq, Tuan Nurhafiza, Ahmad Faqih, \& Muhammad Hilmi, 2019). Malahan, ekonomi kedua-dua negara juga saling bergantung antara satu sama lain. Malaysia memerlukan tenaga kerja untuk aktiviti ekonomi yang berjalan dengan rancak dan Indonesia memerlukan Malaysia untuk peluang pekerjaan bagi mengurangkan kadar kemiskinan dalam kalangan rakyatnya. Namun begitu, isu PATI dan isu kemudahan terhadap imigran Indonesia sering kali menimbulkan ketegangan antara kedua-dua negara.

Kemasukan haram ke Malaysia harus dikawal dan sempadan negara harus dianggap sebagai sempadan. Kemasukan PATI secara besar - besaran bukan sahaja memalukan negara secara keseluruhan malah ia turut menimbulkan masalah kepada aspek ekonomi, sosial dan politik negara. Oleh itu, penyelidik terdahulu sering membincangkan faktor-faktor yang menyebabkan PATI datang ke Malaysia dan kajian dilakukan berdasarkan data yang telah diterbitkan. Walau bagaimanapun, kajian ini menekankan pada pandangan dunia PATI sebagai pelaku sosial utama fenomena ini untuk memberikan pandangan berdasarkan perspektif dan pengalaman mereka. Mengumpul data daripada komuniti ini memerlukan masa lebih lama untuk meyakinkan mereka untuk mengambil bahagian dalam kajian ini. Walau bagaimanapun, para penyelidik percaya bahawa pandangan dunia mereka penting untuk dianalisis dan sekaligus dapat memperkukuhkan penguatkuasaan undang-undang di Malaysia. 


\section{Metod Kajian}

\section{Lokasi Kajian}

Kajian ini dilakukan di sempadan antarabangsa, Stulang Laut, Johor dan Pulau Batam, Indonesia. Sempadan antarabangsa ini melibatkan tiga negara iaitu Malaysia, Singapura dan Indonesia. Di samping itu, ia adalah jalan masuk dan keluar yang penting bagi imigran ke Malaysia. Majoriti daripada mereka yang memasuki Malaysia berasal dari Singapura dan Indonesia. Sempadan antarabangsa ini dipilih kerana beberapa faktor. Pertama, ia dipilih kerana kebanyakan PATI Indonesia memasuki Malaysia melalui laluan ini. Mereka yang memasuki Malaysia secara haram menggunakan laluan tidak rasmi melalui perkhidmatan tekong atau mereka menggunakan laluan rasmi tetapi dengan merasuah pegawai penguat kuasa Imigresen. Batam adalah wilayah Indonesia yang terdekat dengan semenanjung Malaysia. Ini adalah salah satu pulau yang terletak di antara perairan Selat Melaka dan Selat Singapura. Kawasan ini berkeluasan sekitar 67 peratus dari kawasan Singapura.

Perbincangan dan kajian telah dilakukan secara berterusan bagi menentukan jumlah informan untuk kajian kualitatif. Walau bagaimanapun, penyelidik terkemuka Creswell (1998) telah mencadangkan untuk mempunyai kurang daripada 10 informan untuk kajian kualitatif dengan menggunakan pendekatan fenomenologi. Ia telah disokong oleh Moser dan Korstjens (2018) dengan menyatakan jumlah informan yang sesuai untuk kajian kualitatif adalah kurang dari 10. Fenomenologi digunakan dalam kajian ini untuk memahami pandangan dunia PATI. Oleh itu penyelidik perlu memberi fokus utama kepada perspektif informan dan memahami bagaimana mereka melihat fenomena sosial mengikut lensa mereka. Creswell (2013) dan Qutoshi (2018) melaporkan bahawa pendekatan fenomenologi memberi tumpuan kepada informan sebagai pelaku sosial utama. Dalam kajian ini, penyelidik perlu memahami fenomena sosial yang berlaku di sekitar mereka mengikut perspektif mereka.

Informan dipilih menggunakan teknik pensampelan bertujuan dan bola salji. Pensampelan bertujuan memerlukan satu set kriteria yang harus dipenuhi oleh informan. Menurut Alvi (2016) dan Rahi (2017), pensampelan bertujuan memerlukan penyelidik untuk menyenaraikan kriteria terlebih dahulu dan menolak sebarang calon yang tidak sesuai dengan kriteria. Dalam kajian ini, kriteria yang telah ditetapkan oleh penyelidik terdiri daripada dua elemen. Pertama, informan mestilah PATI dan kedua, mereka adalah warganegara Indonesia. Kriteria - kriteria ini disenaraikan kerana pelaku sosial utama kajian ini adalah PATI dan masyarakat Indonesia dipilih kerana komuniti itu mempunyai jumlah PATI yang tertinggi di Malaysia. Selain itu, penyelidik yang mempunyai key informant akan meminta bantuan informan tersebut untuk menghubungi informan - informan lain. Dia kemudian akan meyakinkan mereka untuk mengambil bahagian dalam kajian ini. Dengan kata lain, teknik ini disebut teknik pengambilan bola salji.

10 informan yang terdiri daripada 7 lelaki dan 3 wanita dipilih untuk mengambil bahagian dalam kajian ini. Oleh kerana jantina bukanlah kriteria kritikal untuk kajian ini, penyelidik tidak memberi tekanan pada elemen tersebut. 6 orang informan berasal dari Medan, Surabaya, dan empat daripadanya adalah penduduk pulau dari Pulau Kangean. Selain itu, 6 daripadanya masuk ke Malaysia secara haram manakala empat lagi tinggal melebihi tarikh permit mereka. Kesemua daripada mereka mempunyai latar belakang pendidikan yang rendah dan mereka mempunyai pengalaman bekerja di Malaysia dari 8 tahun hingga 31 tahun. Semua informan lelaki bekerja sebagai buruh di sektor pembinaan sementara wanita bekerja di sektor perkhidmatan pembersihan sebagai pembantu rumah.

\section{Instrumen Penyelidikan}

Kajian ini dilakukan menggunakan pendekatan fenomenologi. Pendekatan fenomenologi adalah kajian kualitatif yang bertujuan untuk memahami fenomena sosial mengikut perspektif informan. Kaedah ini mendorong informan untuk bercakap secara bebas berdasarkan pengalaman hidup mereka tanpa dibimbing atau bergantung pada teori. Temu ramah dilakukan melalui temu bual mendalam. Sebelum sesi dimulakan, penyelidik memberi penerangan kepada informan mengenai kajian ini. Temu ramah dilakukan secara berasingan untuk setiap informan selama kira-kira 45 minit hingga satu jam. Informan diajukan dengan soalan terbuka mengikut objektif kajian. Menurut Moser dan Korstjens (2018), sesi 
temu bual melibatkan penyelidik dan informan. Proses temu bual dimulakan dengan soalan umum dan kemudian kepada soalan yang lebih spesifik. Di samping itu, penyelidik tidak boleh mempengaruhi informan, sebaliknya mendorong mereka untuk bercakap dengan bebas. Sesi temu bual dirakam dengan perakam suara. Sebilangan besar informan memberikan kerjasama penuh dalam kajian ini, namun sebilangan dari mereka tidak mahu mengambil bahagian dalam kajian ini pada mulanya. Mereka takut kemungkinan terjebak dengan pihak penguat kuasa kerana berkongsi maklumat mengenai kesalahan mereka. Namun, mereka memberikan kerjasama sepenuhnya setelah pengkaji meyakinkan mereka sesi temu bual ini hanyalah untuk tujuan akademik.

\section{Analisis Data}

Semua temu bual yang dirakam kemudian ditranskripsikan dan dianalisis dengan menggunakan perisian Atlas. Ti. Dengan Atlas. Ti, penyelidik mengekstrak data mengikut ciri-ciri persamaan dan membuat kod untuk menghubungkan segmen data. Dari kod tersebut, penyelidik kemudian membina tema yang dapat merangkumi semua kod di bawah satu bumbung. Tema-tema tersebut dapat menjawab semua soalan kajian.

\section{Perbincangan dan Dapatan Kajian}

Penyelidik mengakui, sorotan karya yang mengulas isu faktor PATI bermigrasi ke negara penerima dengan meluas. Sebilangan besar kajian sebelumnya bergantung pada data yang telah diterbitkan, namun nilai tambah kajian ini adalah pada PATI itu sendiri dengan data sokongan iaitu data sekunder seperti jurnal, prosiding persidangan dan buku. Kajian sebelumnya menunjukkan pelbagai pendekatan untuk menganalisis faktor migrasi seperti faktor tolakan dan tarikan, mikro dan meso dan teori ekonomi neoklasik dan baru. Walau bagaimanapun, kajian ini menggunakan pendekatan umum yang merupakan aspek ekonomi dan sosial. Ini adalah kerana pendekatan melalui teori yang spesifik akan menjadi penghalang untuk memahami pandangan PATI secara keseluruhan.

Malaysia dan Indonesia mempunyai persamaan sosiobudaya. Keseragaman budaya terdiri daripada tiga elemen iaitu agama, bahasa dan nilai dan tradisi sosial. Ciri-ciri persamaan budaya Malaysia dan Indonesia merangkumi ketiga-tiga elemen ini sekali gus mengeratkan hubungan persaudaraan antara kedua-dua negara jiran. Contohnya, agama rasmi kedua-dua buah negara adalah Islam. Sementara itu, Bahasa Melayu adalah bahasa rasmi di Malaysia dan Bahasa Indonesia adalah bahasa rasmi di Indonesia. Selain itu, kedua-dua negara mempunyai nilai dan tradisi sosial yang serupa seperti menghormati orang tua, meraikan tetamu dan meraikan perayaan seperti Hari Raya Aidilfitri, Hari Raya Qurban dan Maulud.

\section{Ekonomi}

\section{Keperluan}

Semua informan menyentuh aspek ekonomi sebagai salah satu faktor mereka berhijrah ke Malaysia. Bermigrasi ke Malaysia adalah satu keperluan bagi mereka kerana di sini adalah lubuk pengeluaran. Informan ketiga menyebut, " Kita masih datang sini sebab kita penghasilannya itu ada disini. Jadi terus dilawan gitu. Biarlah habis banyak mana modal tu kan".

Sementara itu, informan empat menyatakan, "mereka bisa merasa kalau kerja di negara orang lain ini, di negara Malaysia ini mereka itu bisa membantu biaya ekonomi itu untuk meningkatkan yang ada di Indonesia seperti itu". Di samping itu, informan sepuluh menyatakan," Saya dulu, masih datang Malaysia lepas kena tangkap sebab kalau tak, habis kita mau cari rezeki mana? Di sini pendapatan. Anak lah penguat semangat saya kembali ke sini 2017. Tapi kalau saya tak cari kerja, dia mahu makan apa." 
Selain itu, mereka juga bercakap mengenai simpanan sebagai salah satu tujuan mereka ingin bekerja di Malaysia. Informan tiga memberitahu, "Orang susah di kampung saya boleh dikatakan 30 percent lah. Yang lain tu kesini lah penghasilannya, macam orang Madura , memang disini. Kalau bekerja dekat sana, jangan harap dapat rumah". Sementara itu, informan enam menyebut, "Kita ramai kerja sini, kerna mahu bina rumah di sana. Ramai yang sukses jugala”.

Daripada dialog tersebut, informan-informan menyatakan bahawa mereka harus bekerja di Malaysia untuk mencapai matlamat mereka. Contohnya, membina rumah yang lebih baik untuk keluarga mereka di Indonesia dan mempunyai wang yang cukup untuk menghantar anak-anak mereka ke sekolah. Dengan kata lain, mereka harus bekerja di luar negara terutama di Malaysia untuk mempunyai akses kepada keperluan asas seperti pendidikan dan kediaman.

\section{Peluang Pekerjaan}

Selain keperluan, peluang pekerjaan turut berperanan dalam menarik PATI untuk berhijrah ke Malaysia. Informan pertama menyatakan, "orang Batam masih mahu kerja di Malaysia kerana masih ada agen kerana di Batam tidak ada kerja. Masih ramai orang Batam ke Malaysia kerana ramai orang Batam menganggur". Informan dua menambah, " Masyarakat di Batam ada juga larang pergi Malaysia secara haram tapi nak buat macam mana tiada kerja kena pergi juga". Suradji (2006) dan Kaur (2015) menyatakan, kegiatan ekonomi yang pesat di Malaysia membuka lebih banyak peluang pekerjaan dalam sektor pembinaan, pertanian dan pembantu rumah. Informan tujuh pula menambah, "Saya suka kerja di Malaysia kerana kerja itu enak. Kalau di Singapore, kerja nggak ada." Sementara itu, informan sembilan mengatakan," Faktor di sana, macam mana ya, penduduknya ramai. Kerjanya tak ada. Dah tu nanti atas sana tu korupsi. Banyak korupsi kan. Yang kecik ditindas terus. Jadi macam mana dia mahu hidup." Dapatan kajian ini sejajar dengan kajian yang dilakukan oleh Fariastuti dan Mohd Khairul Hisyam (2012) yang mendapati bahawa pengangguran yang tinggi di Indonesia menyebabkan orang Indonesia mencari pekerjaan di Malaysia.

Informan juga menyentuh isu permintaan yang berterusan di Malaysia menyediakan peluang pekerjaan untuk mereka. Informan tiga menyebut, "Malaysia sedang membangun la. Banyak permintaan. Lagi lagi orang kampung, tak siap - siap la kampung dia. Nak betul dapur dia lah. Nak tebang pokok dia lah. Jadi tak siap - siap lah. Inshaallah sentiasa ada kerja." Dia menambah lagi, "Kadang - kadang pun bukan kita cari dia, dia cari kita. macam tu la. Sumbernya di situ la, sebab kita bekerja. Contohnya bila kita dalam sebuah rumah buat, datang la tamu - tamu $t u$ semua kan. Siapa buat rumah $n i$, orang $t u$ tunjuk $l a$ kita yang buat. Dia kenal di situ je. Kita tak cari orang $t u$. Dia cari kita." PATI yang sebati dengan budaya penduduk tempatan sehingga mereka dapat bergaul akrab dengan mereka dan mewujudkan hubungan sosial yang utuh. Justeru, hubungan ini dapat menguntungkan PATI dengan memperoleh pekerjaan dari jaringan sosial bersama penduduk tempatan. Suradji (2006) menyatakan, majikan di Malaysia lebih memilih untuk bekerja dengan orang Indonesia kerana Malaysia dan Indonesia adalah negara serumpun yang mempunyai pelbagai persamaan sosiobudaya seperti agama, budaya dan bahasa.

\section{Upah yang Tinggi}

Seterusnya, PATI ingin berhijrah di Malaysia adalah kerana upah yang tinggi. Upah tinggi disebut dalam ekonomi neoklasik dikenali sebagai analisis kos faedah. PATI akan meramal berapa banyak pendapatan yang dapat mereka terima dari tanah air mereka dan dari negara penerima (Douglas \& Espinosa, 1997). Menurut informan, mata wang Ringgit Malaysia lebih tinggi daripada Rupiah yang menyebabkan upah di Malaysia lebih tinggi daripada Indonesia. Seperti yang disebut oleh informan ketiga, "faktor paling penting kita ke Malaysia ni dari segi gaji lah. Iya kan, dari segi duit contohnya. Kalau kita dapat gaji sini rm100 perhari. Duit 100 tu kalau ditukarkan ke duit kita 300 ribu rupiah. Kalau kerja sana, baru dapat 90 ribu. Paling rendah 70 ribu." Sementara itu, informan empat mengatakan, "saya pilih Malaysia, kerna Malaysia tu dia lebih, nilai wangnya itu lebih besar, dari Indonesia matawangnya itu kecil. Gaji saya di Indonesia satu juta setengah untuk 1 bulan. RM500 ringgit Malaysia. Kalau disini dapat RM950 sebulan." Informan lapan menambah, "dekat kampung mau kerja apa. Sana ada kerja tapi kalau orang tak suka memang tak boleh kerja sana, pasal kat sana mata 
duit $t u$ pergi mincing je, pergi laut. Kalau buat macam buat-buat projek $n i$, ada la, tapi cmtu la. 80,000 gaji memang sudah tinggi la tu di sana. Kalau sini satu ringgit, 3000 duit sana." Ia disokong oleh Suradji (2006) dengan menyatakan perbezaan antara gaji Malaysia dan Indonesia adalah signifikan untuk pekerjaan yang sama. Walau bagaimanapun, dapatan kajian itu tidak selaras dengan (Fariastuti \& Mohd Khairul Hisyam, 2012) yang menemui dapatan yang bertentangan dengan dapatan kajian yang popular. Mereka menyebut pekerja Indonesia di Malaysia berkemungkinan tidak miskin, sebaliknya mereka adalah golongan yang mendapat gaji yang tinggi di Indonesia tetapi lebih suka bekerja di Malaysia.

Seperti yang telah dibincangkan oleh informan di atas, beberapa elemen telah diketengahkan dari segi aspek ekonomi. Elemen tersebut adalah keperluan, peluang pekerjaan dan upah yang lebih tinggi. Semua elemen ini boleh dikelaskan sebagai faktor tolakan dan tarikan iaitu teori yang telah dijelaskan lebih lanjut dalam tinjauan literatur. Menurut Haug (2008) imigran yang tidak boleh mendapat akses kepada pasaran modal di tanah air mereka dikategorikan sebagai faktor tolakan sementara pasaran modal di negara penerima diklasifikasikan sebagai faktor penarik. Oleh kerana ekonomi di Malaysia terus berkembang, ia menarik banyak PATI dari negara jiran untuk bekerja di Malaysia. Antara tarikan tersebut adalah peluang pekerjaan, upah yang lebih tinggi berfungsi sebagai faktor penarik. Selain daripada itu, elemen seperti keperluan merupakan faktor tolakan. Dapatan kajian ini adalah konsisten dengan Ridwan (2018) yang menyatakan faktor penolak seperti pengangguran, perbezaan gaji, kemiskinan, lemahnya penguatkuasaan undang-undang dan kurangnya koordinasi antara agensi dan kerajaan. Sementara itu, Tunira (2015) menambah faktor tolakan penghijrahan Indonesia ke Malaysia turut merangkumi aspek ekonomi dan politik.

\section{Sosiobudaya}

\section{Bahasa}

Selain daripada ekonomi, aspek sosial juga mempengaruhi keputusan PATI untuk migrasi ke Malaysia. Hampir semua informan membincangkan mengenai penggunaan bahasa yang sama di Malaysia dan Indonesia yang menjadikan mereka senang untuk bergaul dengan penduduk tempatan. Informan kedua memberikan respons ringkas yang menyatakan, "Saya pilih Malaysia kerna bahasa Malaysia dengan Indonesia bahasa hampir sama." Informan ketiga menambah, "hobi kita pilih Malaysia, maksud hobi kita $t u$ senang hati kita la. Pasal Bahasa Malaysia, atau budaya tu lebih kurang je dengan Indonesia." Sementara itu, responden empat menjelaskan, "Malaysia ini gini lo kenapa saya pilihnya, kalau kita lihat, segi Bahasa itu, lingkungan itu sama dengan Indonesia. Dia tidak dengan negara lain, kalau negara lain itu kan, berbeda Bahasa. Kan dia jadi kita sulit untuk memahami Bahasa mereka, masing - masing kan gitu. Dia juga sulit untuk mengerti kita, kita juga sulit untuk mengerti mereka, jadi kok kalau Malaysia ini kan, bisa dibilang satu rumpun kerna Bahasa itu semua dengan, Indonesia itu sama dengan Bahasa melayunya itu. Jadi kita nggak takut dengan Bahasa mereka itu. Kita bisa mempelajarinya dan kita jugak mengerti bahasanya." Di samping itu, informan lima menambah, "Singapura, kita tak faham apa dia cakap. Indonesia di sana banyak Bahasa jawa. Sini boleh faham, Bahasa sama, macam Bahasa Indonesia, kalau KL." Selain itu, informan enam menyebut, "Kalau macam saya, saya tak ada sekolah, jadi nak Bahasa apa pun saya tak pandai, saya pandai Melayu dan Indonesia lah. Datang sini, saya boleh faham bahasa sini, mula-mula sampai sini, bahasa sini, saya bingung jugak. Terengganu. Lama-lama faham la. Hampir sama dengan Indonesia. Filipina Thailand, lain cerita itu." Malah, penyelidik juga menyedari bahawa informan dapat bercakap dalam dialek Terengganu semasa sesi temubual. Informan ketujuh memberitahu, "Mula-mula datang sini, langsung faham bahasa sini. Sebabnya itu kurang lebih pada sini. Bahasa Indonesia dan Bahasa Malaysia itu sama." Informan lapan pula menyebut, "bahasa memang sama dengan Jakarta, tapi loghat dia tak sama. Kalau Terengganu la. Kalau KL, Johor memang sama la. Dia punya Bahasa, tapi loghat $t u$ lain la. Ada juga kerja di Singapura, Arab, tapi ramai ke sini , sebab Bahasa dia pun bukan susah sangat la kan. Bahasa dia sikit2 sama dengan Bahasa Indonesia. Cuma yang lain, loghat je yang lain. Kalau pergi Arab tu kan, kena belajar dulu Bahasa dia kan, baru boleh lepas masuk la. Sini terus datang boleh kerja." Dapatan kajian ini selari dengan (Maiwan, 2012; Hanafi, Syed Abdul Razak, \& Abdullah, 2018) bahawa kedua-dua negara jiran mempunyai hubungan yang sangat kuat kerana identiti homogen mereka seperti bahasa dan budaya. Bahasa Melayu adalah bahasa kebangsaan di Malaysia. Ia mempunyai beberapa ciri homogen dengan Bahasa Indonesia kerana 
DOI: https://doi.org/10.47405/mjssh.v6i9.1052

kedua-dua bahasa berasal dari penutur bahasa Austronesia. Persamaan itu adalah bonus bagi PATI kerana ia adalah alat penting untuk bergaul dengan penduduk tempatan di Malaysia.

\section{Agama}

Elemen seterusnya di bawah aspek sosial adalah agama. Masyarakat Indonesia sangat patuh pada suruhan agama mereka. Oleh itu, sangat penting bagi mereka untuk mencari persekitaran kerja yang baik yang dapat membantu mereka untuk mempraktikkan suruhan agama sebagai orang Islam. Contohnya, masjid. Informan kedua menyebut, "saya pernah kerja di Thailand April hingga Julai 1997. Di Thailand susah nak cari makanan halal itu satu yang saya rasakan. Sama Filipina juga. Ketiga agama. Kalau di Malaysia, kita senang mau pergi solat. Di Thailand, tak tau kita di mana ada masjid. Pasal itu orang Indonesia lebih suka kerja di Malaysia." Malahan, informan tiga menyatakan, " Lebih mudah ke sini. Macam agama, ke masjid, macam ke solat tarawih." Di samping itu, informan sepuluh menyatakan, "saya ke Malaysia hari $t u$ kerana agak elok sikitlah. Kadang Singapore itu kan, kebanyakan bukan orang Islam." Ia disokong oleh (Maiwan, 2012; Hanafi, Syed Abdul Razak, \& Abdullah, 2018) dengan menyatakan penghijrahan berlaku dari Indonesia ke Malaysia dipengaruhi oleh persamaan agama kerana kebanyakan warganegara dari kedua-dua buah negara tersebut beragama Islam.

\section{Budaya}

Selain itu, para informan juga membincangkan faktor-faktor mereka bermigrasi ke Malaysia dalam aspek budaya. "Hobi kita pilih Malaysia, maksud hobi kita tu senang hati kita la. Pasal Bahasa Malaysia, atau budaya $t u$ lebih kurang je dengan Indonesia." kata informan ketiga. Informan lima pula menyebut, " Kalau sini, Kelantan sama Terengganu macam Jawa. Kalau lain, bandar semua. Adat kampung kampung itu sama. Meraikan tetamu. Kelantan sama Terengganu."Informan 10 menambah, " Orang pun sama, maksudnya akrab ramah, itu la yang membuat kita senang dekat Malaysia. Kat sana ada juga Kristian, buddha tapi kita kan masing masing. Macam di sini la Cina, India." Elemen budaya ini turut dibincangkan oleh Maiwan (2012), Hanafi, Syed Abdul Razak dan Abdullah (2018) bahawa persamaan budaya adalah faktor tarikan bagi orang Indonesia untuk pergi ke Malaysia.

\section{Norma Sosial}

Seterusnya, informan juga menyentuh isu kemasukan ke Malaysia secara haram adalah norma sosial di Indonesia. Seperti yang dikatakan oleh informan ketiga, "Kebanyakan masuk sini betul tak betul dalam 50 percent tapi tu perkara biasa di Indonesia." Informan empat menambah, "Kalau di Indonesia biasa aja kerja tidak sah di Malaysia." Di samping itu, informan lima menyebut, "ramai kawan-kawan saya kerja tak sah disini. 90percent. Sana bukan tak ada kerja, ada, tapi ini sudah kebiasaan. Tak boleh lari dari kebiasaan. Maksudnya, kebiasaannya orang Indonesia memang datang kerja disini. Dekat sana bukan tak ada pekerjaan, banyak jugak. Cuma kebiasaan kita, pergi ke sini." Penghijrahan masyarakat Indonesia ke Malaysia adalah satu budaya di Indonesia. Ini adalah amalan biasa bagi mereka. Spaan dan Naerssen (2018) menyebut, cerita dari mulut ke mulut, sokongan dari broker dan iklan mengakibatkan 'budaya' penghijrahan'. Tradisi ini berlaku kerana keadaan kerja dan kehidupan yang tidak memuaskan di tanah air. Sosiobudaya kedua-dua buah negara ini terdiri daripada bahasa, agama dan budaya membantu PATI untuk mewujudkan hubungan sosial yang harmoni dengan penduduk tempatan. Melalui hubungan sosial, mereka dapat bergaul dan bermesra dengan masyarakat tempatan di Malaysia dan mendapat pekerjaan daripadanya. Ia disokong oleh Suradji (2006), Kaur (2015), Tunira (2015), Ridwan, 2017), majikan Malaysia lebih selesa bekerja dengan orang Indonesia kerana mereka mahir dengan peraturan sosial penduduk tempatan. Identiti sosial yang sama sering disebut sebagai negara serumpun (Clark, 2015). Walaupun begitu, tidak ada penemuan yang menunjukkan jaringan sosial sebagai faktor kritikal bagi PATI untuk memilih Malaysia sebagai destinasi pertama mereka, dapatan kajian ini tidak selaras dengan Hanafi, Syed Abdul Razak dan Abdullah (2018) yang menemui jaringan sosial PATI dengan mandat, broker tempatan yang memainkan peranan penting dalam membantu proses pengambilan pekerja. Ia tidak termasuk masyarakat tempatan di Malaysia. 


\section{Kesimpulan}

Empat kesimpulan dapat dibuat daripada dapatan kajian. Pertama, kebanyakan informan menyentuh aspek ekonomi dan sosial sebagai faktor utama untuk mereka berhijrah ke Malaysia. Ini menunjukkan bahawa PATI membuat keputusan untuk berhijrah kerana keadaan ekonomi dan persamaan sosiobudaya di kedua - dua buah negara tersebut. Faktor ekonomi menarik mereka untuk migrasi ke Malaysia, tetapi faktor sosiobudaya adalah yang membuat mereka kekal bertahan di Malaysia. Dengan kata lain, keperluan, peluang pekerjaan dan gaji yang lebih tinggi adalah penyebab mereka berhijrah ke Malaysia, tetapi bahasa, agama, budaya dan norma sosial menjadikan mereka tinggal dan bertahan di Malaysia. Sebagai contoh, mereka datang ke sini untuk mendapatkan peluang pekerjaan, namun hubungan sosial yang terjalin di kalangan penduduk tempatan dapat membantu mereka untuk mendapat pekerjaan secara berterusan.

Kajian terdahulu kurang memberi penekanan pada aspek sosial yang mana elemen-elemen tertentu diabaikan. Kepercayaan popular sering membincangkan identiti homogen Malaysia dan Indonesia dan hubungan yang erat antara kedua-dua buah negara. Tetapi perbincangan mengenai perkara tertentu seperti aspek sosial tidak diberi perhatian. Dalam kajian ini, penyelidik dapat menyimpulkan bahawa kebanyakan responden sangat berpegang teguh pada asal usul dan identiti mereka. Mereka tidak melihat wang sebagai tujuan utama tetapi juga elemen lain yang bersifat rohani dan agama. Contohnya, mereka mahukan persekitaran kerja mereka yang membolehkan mereka untuk melakukan suruhan agama Islam seperti masjid dan makanan halal untuk dimakan. Sebilangan daripada mereka bersedia untuk melepaskan pekerjaan mereka jika persekitaran pekerjaan itu tidak memenuhi kriteria mereka.

Dapatan kajian ini tidak konsisten dengan teori ekonomi neoklasik kerana teori tersebut hanya menekankan analisis kos faedah sebagai penyebab penghijrahan. Antara yang dibincangkan dalam analisis kos faedah adalah upah yang lebih tinggi, tetapi itu bukan satu-satunya faktor penghijrahan ke Malaysia. Selain itu, kajian ini tidak selari dengan teori ekonomi baru yang mengemukakan faktor dari sudut rumah tangga seperti kegagalan pasaran di Indonesia. Pada tahap yang terbatas, memang benar masalah di negara asal seperti kemiskinan adalah motif utama untuk migrasi, namun aspek lain seperti tarikan - tarikan yang ada pada negara penerima tidak boleh diabaikan. Kajian ini menunjukkan pelbagai elemen yang terdapat di negara penerima yang bertindak sebagai faktor penarik kepada penghijrahan seperti gaji dan peluang pekerjaan yang lebih tinggi.

Walaupun demikian, teori tolakan dan tarikan paling sesuai dengan dapatan kajian ini kerana teori ini tidak hanya memfokuskan pada tanah air dan negara penerima, tetapi juga mengambil kira penilaian kepada faktor peribadi seperti jaringan sosial, halangan, dan kehilangan modal di negara asal. Unsurunsur ini merangkumi semua penemuan yang dikategorikan dalam aspek ekonomi dan aspek sosial.

\section{Rujukan}

Ali, A., Ellias, D. A., \& Mobin, K. (2020). Mexican immigrants challenges for American Identity. Journal of Critical Reviews, 7(6), 945-950. doi:doi:10.31838/jcr.07.06.164

Alvi, M. (2016). A Manual for Selecting Sampling Techniques in Research. Munich Personal RePEc Archive, 1-56.

Anggoro, T. (2019). Identification of push factor, pull factor, and negative information concerning to migration decision. (Evidence from West Nusa Tenggara). International Journal pf Scientific and Technology Research, 8(1), 138-144.

Boswell, C. (2002). Addressing the causes of migratory and refugee movements: the role of the European Union . Institute for Peace Research and Security Policy, 1-27.

Clark, M. (2015). Labour migration flows and regional integration in Southeast Asia. International Institute for Asian Studies, 100-113.

Creswell, J. (1998). Qualitative Inquiry and Research Design : Choosing Among Five Traditions. California: Sage.

Creswell, J. (2013). Qualitative Inquiry and Research Design. California: Sage. 
Dorigo, G., \& Tobler, W. (1983). Push - pull migration laws. Annals of the Association of American Geographers, 73(1), 1-17.

Douglas, M. S., \& Espinosa, K. E. (1997). What's Driving Mexico - U.S Migration? A thereotical, empirical, and policy analysis. American Journal of Sociology, 102(4), 939-999.

Fariastuti, D., \& Mohd Khairul Hisyam, H. (2012). Dynamics of Push and Pull Factors of Migrant Workers in Developing Countries : The Case of Indonesian Workers in Malaysia. Journal of Economics and Behavioral Studies, 4(12), 703-711.

Hanafi, H., Syed Abdul Razak, S., \& Abdullah, K. (2018). Migrant Workers: Illegal Recruitment and Travelling from Indonesia to Tawau (Sabah), Malaysia. Borneo Research Journal, 12, 1-16.

Haug, S. (2008). Migration networks and migration decision making. Journal pf Ethnic and Mogration Studies, 34(4), 585-605.

Hazan, M. (2014). Understanding return migration to Mexico: towards a comprehensive policy for the reintegration of returning migrants. Center for Comparative Immigration Studies, 1-51.

Kaur, A. (2015). Malaysia : irregular movements and regional policies. International Institute for Asian Studies, 76-98.

Lee, E. (1966). A Theory of Migration. Demography, 3(1), 47-57.

Leigh, A. (2012, September 12). Why Don't Some Countries Sign the Refugee Convention. Retrieved from AndrewLeighMP: https://www.andrewleigh.com/3253

Maiwan, M. (2012). Antara benci dan rindu: hubungan Indonesia - Malaysia dan isu tenaga kerja ilegal di Malaysia. Jurnal Ilmiah Demokrasi, 11(2), 19-34. doi:10.21009/jimd.v11i2.4053

Martin, S., Tuiran, R. A., Corona, R., \& Lafield, K. W. (1997). Binational Study on Migration between Mexico and the United States. Mexico: U.S. Commission on Immigration Reform \& DF: Mexican Ministry of Foreign Affairs.

McBrien, J. L. (2017). Refugees, asylum seekers, and other immigrants. Social Studies Research and Practice, 12(2), 113-124. doi:https://doi.org/10.1108/SSRP-03-2017-0001

Montano, R. (2017). Mexicans in the United States: A historical perspective, 1900-1942. 1-53.

Moser, A., \& Korstjens, I. (2018). Series : Practical Guidance to Qualitative Research, Sampling, Data Collection and Analysis. European Journal of General Practice, 9-18.

Nava, J. (1970). Mexican Americans: a brief look at their history. Anti - Fefamation League og B'nai B'rith, 2-56.

Pabalik, D., Hatta, M., Nur, H., Rinaldy Bima, M., \& Djanggih, H. (2020). Characteristics of Criminal Acts of Corruption in Indonesia. International Journal of Psychosocial Rehabilitation, 2596-2608. doi:DOI: 10.37200/IJPR/V24I8/PR280279

Phillips, J. (2011). Asylum seekers and refugees: what are the facts? Parliamentary Library, 1-15.

Qutoshi, S. (2018). Phenomenology : A Philosophy and Method of Inquiry. Journal of Education and Educational Development, 215-222.

Rahi, S. (2017). Research Design and Methods : A Systematic Review of Research Paradigms, Sampling Issues and Instrument Developments. International Journal of Economics and Management Science, 1-5.

Ridwan, W. (2017). Illegal journey : the Indonesian undocumented migrant workers to Malaysia. Populasi, 25(2).

Ridwan, W. (2018). Illegal journey : the Indonesian undocumented migrant workers to Malaysia. Jurnal Kependudukan dan Kebijakan Universiti Gajah Mada, 25(2), 24-43. doi: 10.22146/jp.36202

Spaan, E., \& Naerssen, T. (2018). Migration decision - making and migration industry in the Indonesia Malaysia corridor. Journal of Ethnic and Migration Industries, 44(4), 680-695. doi:https://doi.org/10.1080/1369183X.2017.1315523

Suradji. (2006). Penangan pekerja migran di Malaysia. Jurnal Ilmu Administrasi, 3(3), 224-231. doi:https://doi.org/10.31113/jia.v3i3.425

Taufiq, A., Tuan Nurhafiza, R., Ahmad Faqih, I., \& Muhammad Hilmi, M. (2019). Kerjasama dua hala Malaysia dan Indonesia: sudut pandang dari hubungan diplomatik. Journal of Law \& Governance, 2(1), 28-38.

Thomas, S. (2012). Corruption Pattern in Indonesia : A Geograhical Analysis. Journal of Economics and Policy.

Tunira, H. (2015). Potential social capital of Indonesian immigrant in Malaysia : A preliminary research. 2nd Global Conference on Business and Social Science (pp. 383-389). Bali: Procedia Social and Behavioral Sciences. doi:https://doi.org/10.1016/j.sbspro.2015.11.050 
Malaysian Journal of Social Sciences and Humanities (MJSSH), Volume 6, Issue 9, (page 84 - 95), 2021

DOI: https://doi.org/10.47405/mjssh.v6i9.1052

Warner, J. A. (2005). The social construction of the criminal alien in immigration law, enforcement practice and statistical enumeration: consequences for immigrant stereotyping. Journal of Social and Ecological Boundaries, 56-80.

Zuraidah, M., \& Lee, C. (2014). Representing immigrants as illegals, threats and victims in Malaysia: Elite voices in the media. Discourse \& Society, 25(6), 687-705. doi:DOI: $10.1177 / 0957926514536837$ 